\title{
ARTIKEL REVIEW : Konsep Contingency serta Peranan Moderating dan Mediating Variable dalam FP
}

Nama : Arvin Winatha

Email : $\underline{\text { 130119032@student.ubaya.ac.id }}$

Contingency Theory merupakan teori yang mengadopsi pendekatan kontingensi untuk memahami dampak Strategic Orientation (SO) terhadap performa perusahaan dalam konteks Turbulensi Teknologi (TT) yang dinamis. Contingency Theory memiliki premis dasar yaitu bahwa perusahaan mencapai kinerja terbaik ketika struktur perusahaan relevan untuk menangani hal-hal kontinjensi yang berlaku berdasarkan ukuran perusahaan, teknologi, dan lingkungan. Contignency Theory bertujuan untuk memahami bagaimana perusahaan menyelaraskan harapan kinerja mereka dengan lingkungan bisnis internal dan eksternal. Teori ini memandang bahwa lingkungan eksternal merupakan determinan utama FP. (Pratono, Strategic orientation and information technological turbulence: contingency perspective in SMEs, 2016)

Mendefiniskan Teknologi sebagai Variabel Moderasi menawarkan konsep teknologi yang holistik bagi nilai bisnis. Kemampuan teknologi meningkatkan harapan perusahaan untuk mencapai kinerja yang lebih baik. Turbulensi Teknologi (TT) berfungsi sebagai faktor kontingensi primer atau Independen yang difokuskan pada SO sebagai determinan utama FP. TT memiliki efek moderasi aktif hubungan antara SO dan FP. Di bawah tingkat TT yang rendah, SO memiliki dampak positif terhadap peningkatan Firm Performance. Disisi lain, di tingkat TT yang tinggi mengubah hubungan positif menjadi negatif dimana adanya SO yang tinggi mengakitbatkan penurunan Firm Performance. (Pratono, Strategic orientation and information technological turbulence: contingency perspective in SMEs, 2016)

Pandangan tradisional menunjukkan bahwa resiko tinggi berpotensi menawarkan hasil yang tinggi dengan memperkenalkan Turbulensi teknologi informasi sebagai variable moderasi dan juga Risk Taking Behavior sebagai variable Independent. 4 variabel latent yang dapat digunakan untuk mengukur tingkat pengelolaan resiko yang terdiri dari risk taking behavior, firm performance, pricing capability, dan information technological turbulence. Hasilnya risk taking behavior berpengaruh positif terhadap FP dan tingkat Turbulensi teknologi yang tinggi mengurangi efektivitas perilaku pengambilan resiko pada $F P$. Selain itu hasil regresi dengan variable moderasi teknologi informasi menunjukkan bahwa perilaku pengambilan resiko terhadap FP kurang efektif di bawah IT Turbulence yang tinggi. (Pratono, 2018)

Entrepreurial autonomy telah diakui sebagai elemen utama atau Variabel Independent dalam perilaku kewirausahaan perusahaan untuk menciptakan Entrepreneurial Value. Perusahaan yang menghadapi hubungan yang kompleks antara kemampuan penetapan harga dan kinerja, membutuhkan sebuah variable moderasi yang bisa menjelaskan antar hubungannya. Yang sebagaimana dapat dipahami dalam peran turbulensi teknologi sebagai moderating variable dalam hubungannya dengan Pricing Capability dan Firm Performance. Otonomi memiliki hubungan positif dan dampak yang signifikan terhadap FP. Namun di bawah Turbulensi teknologi yang tinggi akan mengubah dampak positif menjadi negatif. Dimana perusahaan dengan tingkat otonomi yang tinggi ini lebih banyak cenderung gagal dalam mengidentifikasi strategi penetapan harga terbaik untuk mencapai firm performance yang diharapkan (Pratono, Ratih, \& Arshad, 2018). 
Dalam dunia bisnis saat ini, kelangsungan hidup perusahaan sangat bergantung pada kemampuan inovatifnya. Dalam hal ini Firm Profitability bertindak sebagai Variabel Dependent dan Collaboration Distance sebagai Variabel Independent. Terdapat hubungan yang kuat antara Inventor Distance (Geografis) atau jarak kolaborasi dengan Firm Performance, dan hubungan ini dapat dimoderasi oleh 2 bentuk jaringan kolaborasi yang berbeda yaitu yang pertama di tingkat antar perusahaan dan yang kedua yaitu di tingkat lintas negara. Hal ini menyatakan bahwa jarak geografis antara penemu yang berkolaborasi memiliki efek positif pada FP. Pengaruh jarak geogarfis terhadap kinerja perusahaan pada umumnya lebih rendah pada perusahaan yang memiliki rasio profitabilitas yang lebih rendah sedangkan perusahaan yang memiliki rasio profitabilitas yang tinggi cenderung mendapatkan pengaruh jarak geografis yang lebih tinggi terhadap kinerjanya. (Moaniba, Su, \& Lee, 2020)

Mediating effect disini diartikan sebagai efek yang dihasilkan dari adanya Variabel mediator yang saling menghubungkan Independent variable dan Dependent Variabel. Tujuan Variabel mediator adalah menjelaskan hubungan antara $I V$ dan $D V$. Variabel Mediator merupakan variable perantara atau penengah antara Independent variable (IV) dengan Dependent variable $(D V)$ hal ini diperlukan sehingga antar variable bisa bekerja secara baik atau mediating effect dikatakan sukses. (Wang, Wang, Chen, Pan, \& Zhang, 2020)

Membangun Trust adalah sebuah elemen fundamental bagi perusahaan, pemasok dan distributor untuk saling memahami satu sama lain. Trust disini berfungsi sebagai Mediating Variable. Trust secara positif memberikan full mediation effect pada hubungannya antara Social Network Structure dan Firm Performance. Trust disini dapat meningkatkan kualitas jaringan, yang mengandalkan kinerja perusahaan dan mendorong perusahaan untuk berinvestasi sumber daya atau resources lebih banyak. Trust juga secara positif memberikan mediation effect penuh pada hubungan antara Social Network Structure dan selling capability. Perusahaan yang dapat membangun kepercayaan pelanggan dari jaringan mereka akan dapat mendorong penjualan. Trust mampu memediasi hubungan antara Social Network Structure dan pricing capability. (Pratono, 2018)

Mediating effect juga dapat dirasakan dimana dalam hubungan antara 3 variabel Selling Capability, Trust, dan Pricing Capability. Dimana Trust memiliki dampak yang signifikan pada Selling Capability dan Pricing capability, hal ini mendapatkan dukungan yaitu ketika Consumer trust membuat perusahaan menjadi makin percaya diri dalam menjual produknya, dan hal ini yang akan berimplikasi pada kemampuan Pricing Capability. Selling capability ini memiliki pengaruh yang signifikan terhadap Pricing Capability dan Pricing Capability ini akan berpengaruh signifikan terhadap firm performance. (Pratono, 2018).

Inter-organizational Learning (IOL) berfungsi sebagai Mediating Variable dalam mendukung hubungan antara Variabel Independen Green Entrepreneurial Orientation (GEO) dan Market Orientation (MO) dan firm competitive advantage. IOL berpengaruh signifikan terhadap firm competitive advantage. Dengan demikian, hubungan tidak langsung melalui mediator IOL mempengaruhi proses transformasi dari GEO menjadi firm competitive advantage dalam model mediator. Ada kecendrungan kuat dalam Studi empiris bahwa $I O L$ berperan sebagai variable intervensi yang beroperasi dengan menerima masukan dari $G E O$, yang dimana berperan sebagai konstruk eksogen. Survei tersebut menunjukkan bahwa jika responden menganggap perusahaan memiliki orientasi kewirausahaan yang hebat, penilaian ini mengarah pada $I O L$ yang lebih tinggi dan secara positif mempengaruhi Firm competitive advantage. IOL memberikan efek mediasi 
positif pada hubungan antara EO, MO dan Firm competitive advantage. Hasilnya memberikan bukti bahwa $I O L$ tidak hanya merupakan sumberdaya yang berharga untuk keunggulan kompetitif tetapi juga membantu perusahaan untuk memanfaatkan $E O$ dan $M O$ dalam keunggulan kompetitif.. (Pratono, Darmasetiawan, \& Jeong, 2019)

\section{Bibliography}

Moaniba, I. M., Su, H. N., \& Lee, P. C. (2020). Geographic distance between co-inventors and firm performance: The moderating roles of interfirm and cross-country collaborations. Technological Forecasting and Social Change, 157. doi:https://doi.org/10.1016/j.techfore.2020.120070

Pratono, A. H. (2016). Strategic orientation and information technological turbulence: contingency perspective in SMEs. Business Process Management Journal, 22(2). doi:https://doi.org/10.1108/BPMJ-05-2015-0066

Pratono, A. H. (2018). "From social network to firm performance: The mediating effect of trust, selling capability and pricing capability". Management Research Review, 41(6 ), 680-700.

Pratono, A. H. (2018). Does firm performance increase with risk-taking behavior under information technological turbulence? Empirical evidence from Indonesian SMEs. Journal of Risk Finance, 19(4), 361-378. doi: https://doi.org/10.1108/JRF-10-2017-0170

Pratono, A. H., Darmasetiawan, N. K., \& Jeong, B. G. (2019). "Achieving sustainable competitive advantage through green entrepreneurial orientation and market orientation: The role of interorganizational learning". The Bottom Line, 32(1), 2-15.

Pratono, A. H., Ratih, R. V., \& Arshad, D. (2018). Does Entrepreneurial Autonomy Foster SME Growth Under Technological Turbulence? The Empirical Evidence from Indonesia. Journal of Technological Behaviour Science, 3, 170-178. doi:https://doi.org/10.1007/s41347-018-0051-9

Wang, L., Wang, Y., Chen, Y., Pan, X., \& Zhang, W. (2020). Performance shaping factors dependence assessment through moderating and mediating effect analysis. Reliability Engineering \& System Safety, 202. doi:https://doi.org/10.1016/j.ress.2020.107034 